\title{
Antisipasi Pengaruh Pemudaran Gelombang (Fading) pada Transmisi Gelombang Mikro Digital dengan Space Diversity dan Frequency Diversity
}

\author{
Endah Sudarmilah \\ Teknik Elektro Universitas Muhammadiyah Surakarta
}

\begin{abstract}
Abstrak
Informasi yang ditransmisikan melalui jaringan telekomunikasi tidak hanya dalam wujud "suara" saja, tetapi dapat pula dalam wujud data, video dan image. Informasi yang berbeda-beda wujudnya tersebut dapat ditransmisikan melalui media yang beragam pula. Salah satu media transmisi yang banyak digunakan saat ini adalah jaringan gelombang mikro.

Komunikasi gelombang mikro banyak diterapkan baik pada komunikasi satelit maupun komunikasi terrestrial. Sebagai komunikasi terrestrial gelombang mikro merambat melalui atmosfer, karena itu gelombang mikro dipengaruhi oleh adanya redaman (pengurangan energi) dan pudaran (fading) akibat efek atmosfer dan relief bumi.

Dengan adanya banyak pengaruh redaman dan pudaran pada berkas gelombang mikro maka perlu diberikan suatu solusi untuk mengatasinya yaitu dengan peragaman (diversity) baik itu peragaman ruang (space diversity) maupun peragaman frekuensi (frequency diversity).
\end{abstract}

Kata Kunci: transmisi, gelombang mikro, peragaman, redaman, pudaran.

\section{Pendahuluan}

Komunikasi memegang peranan penting dalam kehidupan manusia. Pada awalanya kebutuhan berkomunikasi hanya terbatas pada suatu lingkup daerah yang kecil saja, namun semakin lama kebutuhan akan komunikasi antar derah, antar pulau, antar negara, bahkan ke seluruh dunia, sehingga kemudian istilah "telekomunikasi" menjadi tidak asing lagi bagi kita. Seiring dengan berkembangnya tingkat peradaban manusia, teknik bertelekomunikasi pun semakin maju. Berawal dari penemuan telepon oleh Alexander Graham Bell, kemudian menyusul penemuan-penemuan perangkat telekomunikasi modern seperti faksimili, radio, satelit, telepon seluler, dan lain-lain.

Saat ini informasi yang ditransmisikan melalu jaringan telekomunikasi tidak hanya dalam wujud "suara" saja, tetapi dapat pula dalam wujud data, video dan image. Informasi yang berbeda-beda wujudnya tersebut dapat ditransmisikan melalui media yang beragam pula. Salah satu media transmisi yang banyak digunakan saat ini adalah jaringan gelombang mikro.

Sistem transmisi gelombang mikro dapat digunakan untuk komunikasi satelit maupun komunikasi terentrial yang merambat melalui atmosfer, sehingga efek atmosfer sangat mempengaruhi energi dan berkas gelombangnya. Antisipasi hal tersebut adalah dengan adanya space diversity (peragaman ruang) dan frequency diversity (peragaman frekuensi).

\section{Sistem Transmisi Gelombang Mikro (Microwave)}

Sistem transmisi gelombang mikro bekerja pada $\mathrm{GHz}$ ) yang mempunyai panjang gelombang dalam ruang bebas antara $1 \mathrm{~cm}-1 \mathrm{~m}$. sinyal gelombang mikro dipancarkan melalui lintasan lurus dari satu titik ke titik yang lain, dikenal dengan istilah " lintasn garis pandang" atau line of sight (LOS. Stasiun yang digunakan, baik stasium pemencar, penerima, maupun relai ditempatkan pada lokasi yang tinggi pada menara antena yang tinggi pula, agar transmisi dapat mencakup daerah LOS yang maksimum sehingga dapat diperoleh suatu lintasan gelombang yang bersifat langsung (direct signal path).

Propagasi LOS gelombang mikro menggunakan gelombang radio atau RF (Radio Frequency), yang juga merupakan gelombang elektromagnetik. Komunikasi gelombang mikro dapat digunakan untuk komunikasi satelit maupun komunikasi terentrial 